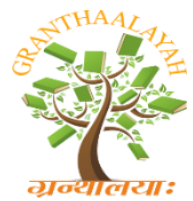

\author{
INTERNATIONAL JOURNAL OF RE
GRANTHAALAYAH \\ A knowledge Repository
}

Science

\title{
INFORMATION TECHNOLOGY USAGE AND CUSTOMER ACCEPTANCE IN THE BANKING SECTOR: A CASE STUDY OF GUARANTY TRUST BANK, KIGALI, RWANDA
}

\author{
John Kwizera ${ }^{1}$, Prof. Raymond Wafula Ongus ${ }^{2}$ \\ ${ }^{1}$ MIS/0067/13, Mount Kenya University, Kigali Campus, P.O Box 5826, Kigali, Rwanda \\ ${ }^{2}$ Mount Kenya University- Kigali Campus, P.O Box 5826, Kigali, Rwanda
}

\begin{abstract}
The study was inspired by the arising issues of concern related to why customer accounts were inactive. The study examined effect of Information technology usage on customer acceptance at GT Bank, Kigali Rwanda. The research design was a case study, with target population of 20,335 customers who used either ATM, Internet banking or mobile banking technologies, 3 e-banking staff and 5 GT Bank branch managers. The data analysis tool used was Statistical Package for Social Sciences (SPSS) version 16.0. Findings revealed that Mobile banking and ATM were mostly used more than Internet banking, depending on features of use and security. ATM features were more accepted compared to Internet banking and Mobile banking features. Multiple regression analysis found $\mathrm{R}$ the coefficient of correlation to be 0.927 signifying a very strong positive correlation between information technology usage and customer acceptance. The coefficient of determination R2 $=0.859$ indicated that $85.9 \%$ of the variability in customer acceptance depended on stochastic model developed, whereas the remaining $14.10 \%$ was attributed to factors beyond the control of the study. The study recommended awareness campaigns about Internet banking technology and the provision of security awareness, to increase trust of customers using information technology.
\end{abstract}

Keywords: Information Technology Usage; Customer Acceptance; John Kwizera; Banking Sector; Banking Technology; Kwizera John.

Cite This Article: John Kwizera, and Professor Raymond Wafula Ongus. (2019). "INFORMATION TECHNOLOGY USAGE AND CUSTOMER ACCEPTANCE IN THE BANKING SECTOR: A CASE STUDY OF GUARANTY TRUST BANK, KIGALI, RWANDA." International Journal of Research - Granthaalayah, 7(12), 86-109. https://doi.org/10.29121/granthaalayah.v7.i12.2019.303.

\section{Introduction}

The term "Banking technology" refers to the use of sophisticated information and communication technologies together with computers to enable banks to offer better services to its customers in a 
secure, reliable, affordable manner and sustain competitive advantage over other banks (Anitha, Saranya \& Vasantha, 2013).

Advances in electronic banking technologies have created novel ways of handling daily banking affairs, especially via the online banking channel (Pikkarainen, Karjaluoto, et al, 2004). Online banking was first offered in the early 1980s as a result of banks striving to provide home banking services and this early online service required the use of the bank's proprietary software (AbuShanab, Pearson \& Setterstrom, 2010). Banks offering electronic banking need to recognize the importance of Internet specific consumer innovation characteristics (Lassar, Manolis \& Lassar, 2005).

Information technologies can help to reduce queues in banking halls if used effectively and efficiently. According to Kamel \& Hassan (2003), the success in the application of different information and communication technology in retail banking delivery channels and payment systems relies to a large extent on the ability of customers to accept and adopt such systems. Also Anitha, Saranya, \& Vasantha, (2013), narrated that banks are using new tools and techniques to find out their customers' needs and acceptance and offer them tailor made products and services to make it convenient and people can take advantage in saving time and distance which was inconvenient in early days. The changes, materializing both from within and external to the financial services industry, result from increasing customer demands for better service response (Ongus \& Lukania 2013). According to Berger \& Nakata (2013), who examined how information communications technologies (ICTs) can be implemented effectively to provide financial service innovations to the poor who live in developing countries and multiple ICT implementation projects in five sub-Saharan African countries (Ghana, Kenya, Malawi,

Mozambique, and Uganda) concluded that; there are multiple factors that should be considered in the design and installation activities surrounding these technologies to ensure they provide costeffective, quality financial services to the poor. For usage of banking technologies to be effective and efficient, it is important to understand the key factors and challenges faced by customers.

According to Guaranty Trust Bank (2015), GTBank is a banking group headquartered in Lagos, Nigeria, and listed on the London Stock Exchange. In 2013, it acquired Fina Bank Group which had been in operation in Kenya for over 25 years with subsidiaries in Rwanda and Uganda. GTBank has been in operation for over 23 years and today operates over 200 branches in Nigeria, Gambia, Ghana, Liberia, Sierra Leone, Cote d'lvoire and the United Kingdom. GTBank online banking is a service that eases and conveniently allows you to bank from the comfort of your home, at work or abroad. You can practically perform almost all the actions that would entail going to any bank branch from your comfort zone. It is important to note that the use of information technology represents a platform for business and socioeconomic development.

According to Kamel (2005), the speed, direction, and determinants of information technology infrastructure directly influence productivity, cost effectiveness, and competitiveness in industries. A range of bank and non-bank deposit-taking institutions, insurance companies and capital markets firms are providing an expanding variety of products and services, positioning the financial sector to contribute to meeting the economic cluster targets of Vision 2020, intended to transform Rwanda into a middle income country. Relatively few of the targets are financial sector specific, 
but a vibrant financial sector is crucial to achieving almost all economic and social objectives (Andrews, Jefferis, \& Murgatroyd, 2012).

According to Guaranty Trust Bank (2016), GT Bank facilitates its customers with information technology tools which include GT Bank Automated Payment System (GAPS); which is a secure web-based service that facilitates the processing in batches or single payments, using secured (https) connections over the Internet. GAPS features are:

1) Role based system that is each user is given a role with specific functions for example Uploader, Reviewer and Approver;

2) Multi-user solution that is supports multiple users for each role;

3) Two-Phase Login that is every user logs in with an access code in addition to a unique username and password;

4) Two factor token authentication that is approvers are issued hardware token devices which generates a dynamic password to authenticate log-in;

5) Multi-level transaction authorization that is no single user can commence and conclude a transaction except otherwise stated on the account mandate;

6) Comprehensive reports are ability to generate payment reports and approval reports;

7) Customizable is the system that can be customized to meet specific requirements. Benefits of GAPS are:

- Elimination of cheque-books;

- Efficient and secure channel for making payments and collections;

- Ability to initiate and monitor payments from any location in the world (in local

- and foreign currency);

- Ease of fulfilling one's obligations in a timely fashion;

- Online real-time access to one's account;

- Configuration flexibility to align with one's payment process flow.

According to Bhulai, Sivasubramanian, Van Der Mei, \& Van Steen, (2007), many Internet applications employ multi-tier software architectures. The performance of such multi-tier Internet applications is typically measured by the end-to-end response times. GAPS is based on 3-tiered model and its' architecture is shown Figure 1.2. The 3-tiered architecture has the following major components:

1) Client: There are two clients for the application. One is a web-based user-friendly client called bank customer. The other is for administration purposes.

2) Application Server: It takes care of the server script, Driver, and checks for the connectivity for mapping to the database in order to fulfill client and administrator's request.

3) Database: Database Servers stores customer's and bank data.

A client initiates a request to the server. The server responds by executing the business logic hosted inside the program and if required, communicates with the Database Server to fulfill a client's request. GTBank offers also mobile banking and Automated Teller Machines services. 


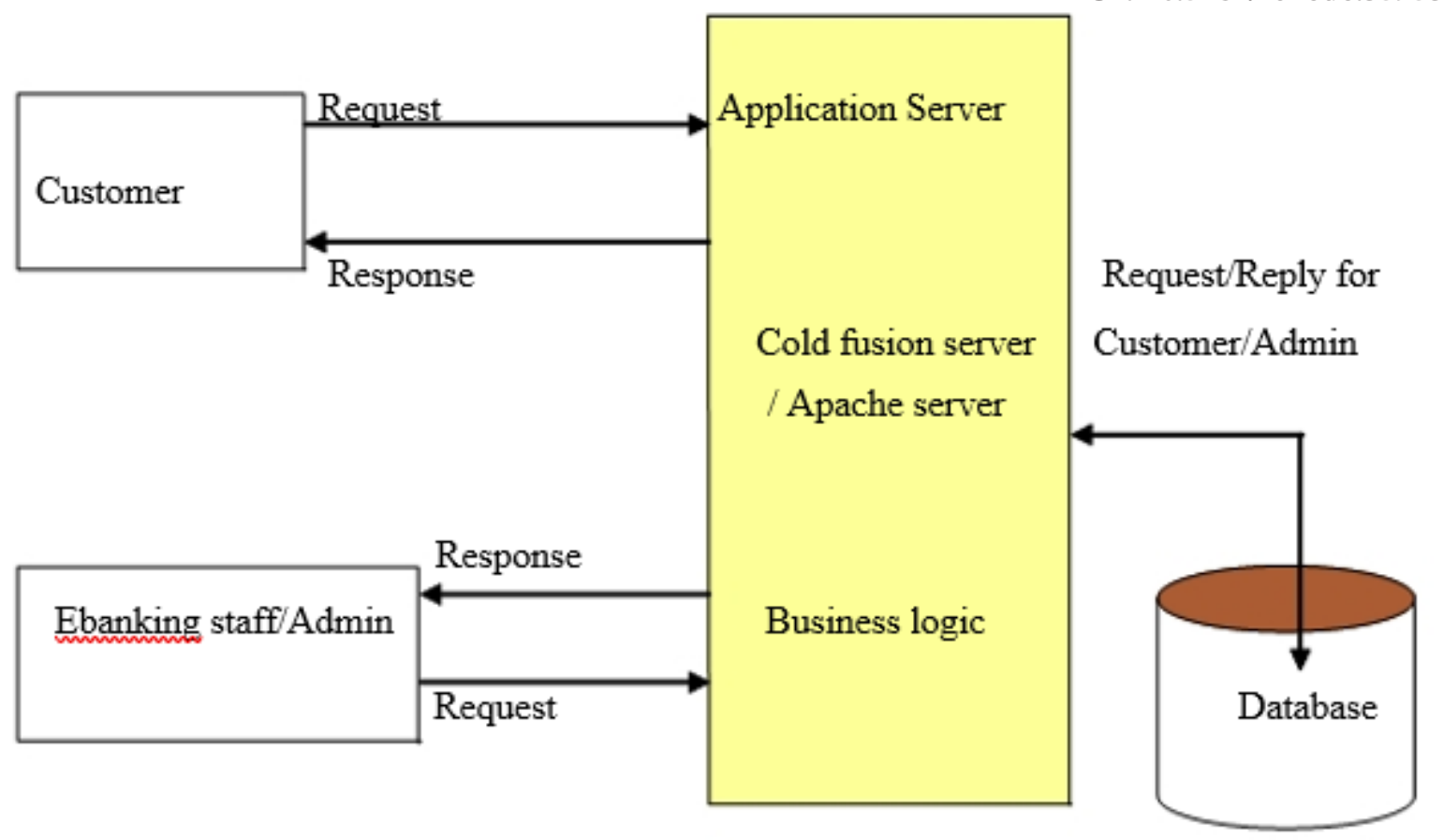

Figure 1.2: Architecture of Online Banking Application

Source: Bhulai, Sivasubramanian, Van Der Mei, \& Van Steen, (2007)

\section{Problem Statement}

Banks have invested and integrated banking technologies to enable their customers to use, access services and product. However, according to research done in Jordan by AbuShanab, Pearson \& Setterstrom (2010), despite the benefits, only 39 percent of potential customers conducted online banking activity and evidence suggests that most customers who have adopted Internet banking also continue to use traditional banking methods. Although millions of dollars have been spent on building Internet banking systems, reports have shown that potential users may not use the systems in spite of their availability (Wang, Lin, \& Tang, 2003).

In Rwanda, as stated by Ngango, Mbabazize \& Shukla (2015), Electronic banking system like ATM, Pay direct, electronic check conversion, mobile telephone banking and E- transact has a great impact on bank performance because they increase profitability, reduce bank cost of operations, and increase bank asset and bank efficiency.

According to Guaranty Trust Bank (2015), GTBank offers a unique bouquet of innovative products and services that help individuals and corporate manage their finances through different technologies which are ATM, E-banking, Mobile banking and Branch banking. The arising issues of concern related to reasons why some customer accounts were inactive despite innovative products of information technologies put in place. It was also not known whether the customers really enjoyed use of information technologies to access their accounts or whether there were various challenges experienced in the process of using the services. Currently, there is a shortage of studies carried out to determine the effect of information technologies in banks, for instance; automated teller machine, Internet banking and mobile banking on customer acceptance in the 
banking sector in Rwanda. Hence the study was to examine how customer acceptance of information technology is influenced by its usage at GT Bank, Kigali, Rwanda.

\section{Objectives of the Study}

The study was undertaken with the following objectives in mind:

\section{General Objective}

The general objective of this study was to examine how customer acceptance of information technology was influenced by its usage at GT Bank, Kigali, Rwanda.

\section{Specific Objectives}

The study was based on the following specific objectives:

- To assess the information technology usage by customers at GT Bank, Kigali, Rwanda.

- To assess customer acceptance in using information technology provided by GT Bank, Kigali, Rwanda.

- To determine the correlation between information technology usage and customer acceptance at GT Bank, Kigali, Rwanda.

\section{Scope of the Study}

The scope of the study included content scope, time scope and geographical scope, explained as follows:

\section{Content Scope}

The study examined usage of information technology at GT Bank (namely; usage of ATM, Usage of mobile banking and usage of Internet banking) while focusing on customer acceptance of the same. In particular the study endeavored to determine how the constructs of the independent variable (information technology usage) affected the construct of the dependent variable (customer acceptance) at GT Bank, as depicted in the conceptual framework.

\section{Geographical Scope}

The study covered Guaranty Trust Bank branches located within Kigali City. The study focused on Nyarugenge, Remera, Niboye and Kimisagara sectors. This is because they provided the same services as other branches in provinces of Rwanda, easy access according to the distance and branches have many customers.

\section{Time Scope}

The study considered data from 2014 to 2016. This is because Guaranty Trust Bank started operating in Rwanda in 2014 and this is when it started installing and implementing the usage of information technology within its premises.

\section{Review of Related Literature}

\section{Critical Review}

Lichtenstein \& Williamson (2006) focused on understanding of how and why specific factors affect the consumer decision, in the Australian context. Guided by Unified Theory of Acceptance and Use of Technology (UTAUT) model, key reasons for non-users not having accepted Internet 
banking were: perceptions that their current banking method was convenient; lack of awareness of the relative advantages; low levels of accessibility, lack of proficiency in the technology, habituated preference for face-to-face or telephone banking services, security and privacy issues, and distrust of the Internet banking technologies.

Adepoju, (2010) argued that ATM technology was advancing and fraudsters were on drawing board to see how they come up with different fraud skills to beat the security. Various forms of fraud were perpetuated, ranging from; ATM card theft, Skimming, Pin theft, Card reader techniques, PIN pad techniques, force withdrawal and lot more as guided by Unified Theory of Acceptance and Use of Technology model and affected customer attitudes towards ATM usage negatively.

AbuShanab, Pearson \& Setterstrom, (2010) and Engwanda (2015) followed Unified Theory of Acceptance and Use of Technology (UTAUT) and indicated that, perceived compatibility, credibility, and costs were the significant predictors of mobile banking acceptance by customers in the United States but other banking technologies were not considered for their acceptance.

Yüksel (2011) in limits of Unified Theory of Acceptance and Use of Technology (UTAUT) model revealed that Internet banking usage rates had increased in the last past years, depending on the increase of educated users. Education and also income level made an important difference in the usage of Internet banking facilities.

According to Aboelmaged \& Gebba (2013) guided by Unified Theory of Acceptance and Use of Technology (UTAUT) indicated a significant positive impact of attitude toward mobile banking and subjective norm on mobile banking adoption. Surprisingly, the effects of behavioral control and usefulness on mobile banking adoption were insignificant. The regression results indicated a significant impact of perceived usefulness on attitude toward mobile banking while the effect of perceived ease of use on attitude toward mobile banking was not supported. Other banking technologies were not considered for their adoption.

According to Mukhtar (2015), evaluated the perceptions of customers towards Internet banking in United Kingdom. Followed Unified Theory of Acceptance and Use of Technology (UTAUT) model to examine different factors affecting the perceptions of customers towards Internet banking which were privacy, security, convenience and trust perceptions of customers towards Internet banking. Revealed that number of people doesn't use Internet banking due to security risk. Mwaikali, (2014), indicated that factors including card locking, insecurity, machine breakdown, machine out of cash, and long time in cash dispensing hindered the convenience, speed, security, reliability and cost for more customers to use ATM and get customer satisfaction in banks in Tanzania. Previous studies emphasized on the factors that influence the acceptance of each of the three banking technologies by customers and indicating which factors affect customer perception on the usage of banking technologies.

\section{Research Gap Identification}

Previous studies by Mwaikali (2014) and Mukhtar (2015), covered banking technologies and influencing factors for the acceptance by customers but left out use of information technology as to impact on customer acceptance, at what level are these banking technologies accepted and which 
is more accepted than others and why, taking case study of Rwanda. This was the knowledge gap that the study intended to fill particularly in the case of GTBank, Kigali Rwanda, where published materials in this area of interest are few. Therefore, the above mentioned gaps were the areas that were covered through this study.

\section{Theoretical Framework}

The study relied largely on the Unified Theory of Acceptance and Use of Technology that uses four determinants (performance expectancy, Effort expectancy, Social influence and facilitating conditions), intention and actual use of banking technologies. The usage of banking technologies is grounded in Unified Theory of Acceptance and Use of Technology. Unified Theory includes (Theory of Reasoned Action, Technology Acceptance theories, Motivational theory, Theory of Planned Behaviour, Personal Computer Utilization theory, Innovation Diffusion Theory, and Social Cognitive Theory). Unified Theory of Acceptance and Use of Technology has emerged as the most powerful and parsimonious theory to represent the antecedents of banking technologies usage (Vijayan, 2005).

\section{Conceptual Framework}

The conceptual framework expresses the rationale behind the study. It reveals and tries to show the relationship between the banking technologies and customer acceptance in GTBank Kigali, Rwanda as shown in Figure 2.6

Independent Variables

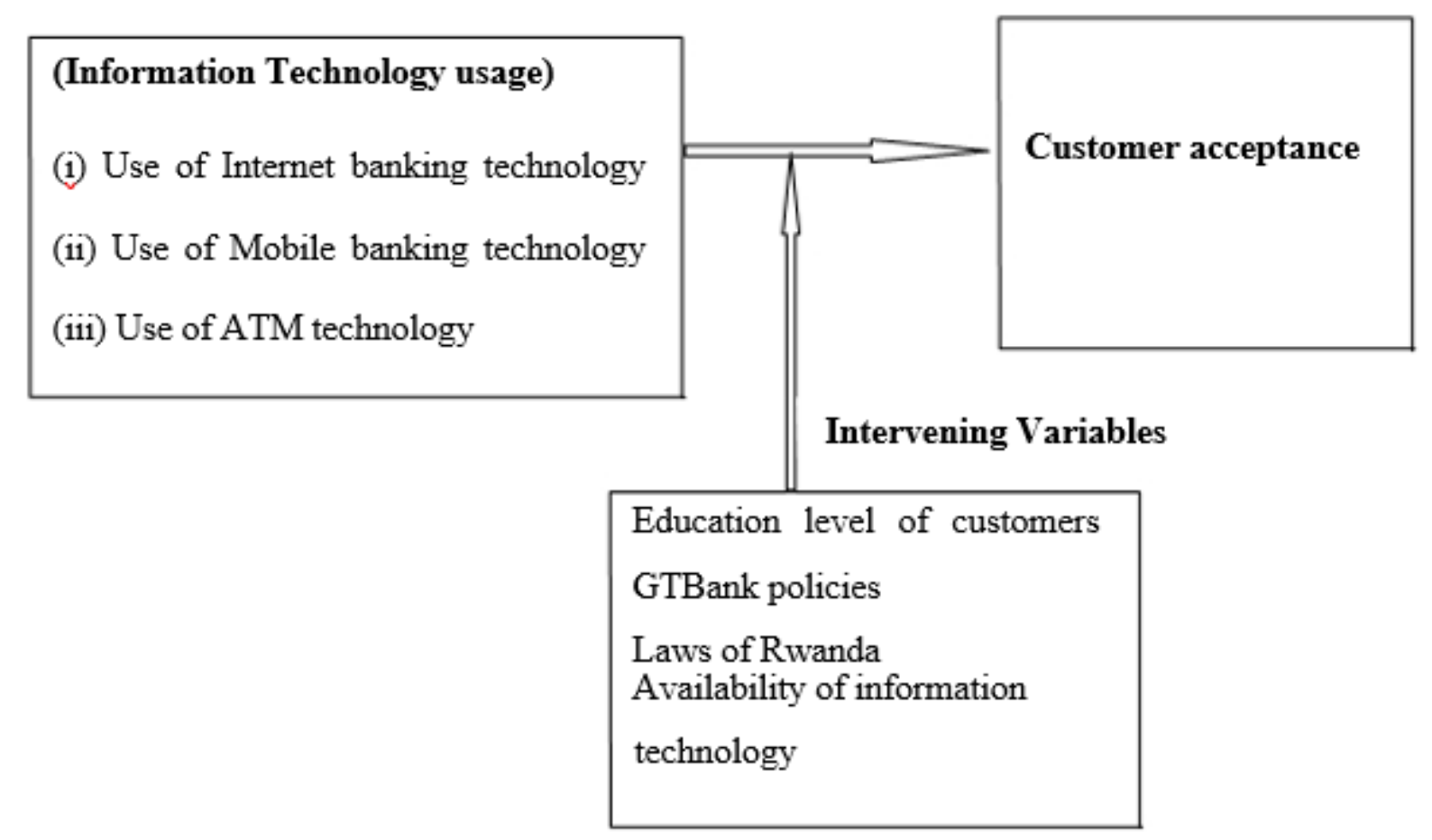

Source: (Preliminary interpretation)

Figure 2.6 Conceptual Framework 
Conceptual framework indicates the relationship between independent variable (information technology usage) and dependent variable (customer acceptance) at GT Bank, Kigali, Rwanda.

\section{Independent Variables}

These include information technology used in the bank (use of Internet banking, use of mobile banking, use of ATM). These are technologies through which customers use to satisfy their needs on financial transactions in Guaranty Trust Bank, Kigali, Rwanda.

1) Use of Internet banking technology

Technology provided by GTBank through which customers perform banking activities via Internet (online banking). This technology would offer customers every service traditionally available through local branches of GTBank, including accepting deposits, paying interest on savings and many other services. Therefore successful customer acceptance of banking technologies in GTBank Kigali Rwanda depended on Internet banking usage. Measuring the customers' perception towards technology acceptance included ease of use and frequency of use. Data was collected using structured questionnaire and interview guide for ebanking staff and branch managers.

2) Use of Mobile Banking Technology

A technology that provided by banks were customers use phones or cellular device to perform financial transactions; monitoring account balances, transferring funds between accounts, bill payments and locating ATM. Operates across all major mobile providers through one of three ways: SMS messaging; mobile web; applications developed for iPhone, android or Blackberry devices; mobile text and alert. Therefore successful customer acceptance of banking technologies in GTBank Kigali Rwanda depended on mobile banking usage. Measuring the customers perception towards technology acceptance included ease of use and frequency of use. Data was collected using structured questionnaire and interview guide for ebanking staff and branch managers.

\section{3) Use of ATM Technology}

The ATM technology is an electronic banking outlet which allows customers to complete basic transactions without the aid of a branch representative or teller. There are two primary types of ATMs; basic units allow the customer to only withdraw cash and receive a report of the account's balance. Complex machines accept deposits, facilitate credit card payments and report account information. Therefore successful customer acceptance of banking technologies in GTBank Kigali Rwanda depended on ATM usage. Measuring the customers' perception towards technology acceptance included ease of use and frequency of use. Data was collected using structured questionnaire and interview guide for ebanking staff and branch managers.

\section{Dependent Variable}

Customer acceptance of banking technologies refer to the levels (high, medium and low) of acceptance in usage of banking technologies. In other words, technology acceptance is measured by the Behavioral Intention (BI) of using the technology therefore customer acceptance levels of Guaranty Trust Bank, Kigali, Rwanda depended on banking technologies usage. Measuring the customers perception towards technology acceptance included ease of use and frequency of use. Data was collected using structured 
questionnaire for customers and interview guide for ebanking staff and branch managers.

\section{Research Methodology}

\section{Research Design}

This study used a case study research design. A case study enabled field research for in - depth analysis of the research problem in the chosen study location. This research design was chosen because it was perceived to be most suitable in clarifying a set of technology usage measures, why they applied, how they impact user acceptance levels and with what result, in the context of GTBank.

\section{Target Population}

The target population for this study was 20,335 customers who used either ATM, Internet banking or Mobile banking technologies, 3 e-banking staff and five branch managers of GTBank, Kigali Rwanda. This number covered all GTBank Kigali Rwanda branches since banking technologies are centralized and are not branch specific, (Jean Paul Niyomugabo, Personal communication, 14 January 2016).

\section{Sample Design}

Sample design involved sample size determination from target population, followed by the application of simple random sampling and purposive sampling techniques respectively.

\section{Sample Size}

For determining of the sample size of customers using GTBank technologies, Yamane's (1967) simplified formula was used as cited by Israel (Israel, 2013) see Table 3.1.

Source: Israel (2013).

Where $\mathrm{n}$ was the sample size, $\mathrm{N}$ was the population and e was the sampling error. The confidence level considered was $95 \%$.

With $\mathrm{N}=20,335$ customers; e=5\%; considering the confidence level of 95\%; $\mathrm{n}$ was equal 393 customers.

Table 3.1 Sample size Determination for Customers

\begin{tabular}{|l|c|c|c|}
\hline Category of respondents & $\begin{array}{c}\text { Target } \\
\text { population }\end{array}$ & $\begin{array}{c}\text { Sample } \\
\text { sizes }\end{array}$ & $\begin{array}{c}\text { Sample } \\
\text { technique used }\end{array}$ \\
\hline $\begin{array}{l}\text { Customers who used either } \\
\begin{array}{l}\text { Automated Teller Machines (ATM), } \\
\text { Mobile banking or Internet banking }\end{array}\end{array}$ & 20,335 & 393 & $\begin{array}{c}\text { Simple Random } \\
\text { Sampling }\end{array}$ \\
\hline e-banking staff & 3 & 3 & $\begin{array}{c}\text { Purposive } \\
\text { Sampling }\end{array}$ \\
\hline Branch managers & 5 & 5 & $\begin{array}{c}\text { Purposive } \\
\text { Sampling }\end{array}$ \\
\hline TOTAL & 20,343 & 401 & \\
\hline
\end{tabular}

Source: Preliminary Interpretation 


\section{Sampling Techniques}

The study employed simple random and purposive sampling techniques respectively. Simple random sampling was considered whereby each individual was chosen entirely by chance and each member of the population had an equal chance of being included in the sample. Purposive sampling was considered because of the unique responsibilities of the respondents (staff from ebanking and branches).

\section{Data Collection Instruments}

Primary data sources included customers of the banking technologies, staff of e-business department and branch managers were targeted by the study. Structured questionnaires were administered to customers and interview guides were used to conduct interviews with e-banking staff and branch managers. Questionnaires were considered because they were less costly, used less time, required less administration effort that was inherent in instruments like interviews and useful in obtaining objective data (Marshall \& Rossman, 2006). Furthermore, questionnaires included standardized answers that made it simpler to compile data. Among the closed ended questions were the use of Likert scales. Likert scale of 5 to 1 was used. $5=$ Strongly agree $4=$ Agree $3=$ Not sure $2=$ Disagree and $1=$ Strongly disagree .

\section{Administration of Data Collection Instruments}

Structured questionnaires were distributed to the branch customers who used banking technologies and an interview guide was used to conduct interviews with the e-banking staff and branch managers of GTBank, Kigali, Rwanda. Branch managers and e-banking staff were selected because they carried out the daily operations and they were more familiar with the usage of banking technologies.

\section{Pilot Study}

The objective of conducting the pilot study was to check on correctness and the clearness of the questions in the instruments, the language used to construct the questions and the importance of the information which is required. The pilot test was conducted with the help of 5 technology customers at I\&M Bank who use the bank's information technology. Interview guide was pretested by means of content analysis. The results of the pilot study were used to modify the data collection tool to make it more understandable and user-friendly to the respondents as well as more effective in collecting the intended data to the targeted respondents.

\section{Reliability}

According to Fraenkel, Wallen \& Hyun (1993), reliability is the degree to which a questionnaire or any measurement method consistently produces the same results on repeated experiments in different studies. Reliability of the study ensures errors in the study are minimized. Firstly to ensure that the content of the questionnaires were valid and reliable, professionals who have knowledge in the area of study were consulted. Their evaluations were included in order to have reliable instruments. 
Table 3.2: Reliability statistics for pilot study of 5 respondents

\begin{tabular}{|l|c|c|}
\hline \multicolumn{1}{|c|}{ Categories } & Number of Items & Cronbach's Alpha value \\
\hline $\begin{array}{l}\text { Customer usage of information technology } \\
\text { provided by GT Bank }\end{array}$ & 4 & 0.833 \\
\hline $\begin{array}{l}\text { Customer acceptance in using information } \\
\text { technology provided by GT Bank }\end{array}$ & 12 & 0.856 \\
\hline $\begin{array}{l}\text { Effect of information technology usage on } \\
\text { customer acceptance at GT Bank }\end{array}$ & 3 & 0.757 \\
\hline
\end{tabular}

Source: Preliminary investigation

Table 3.2 shows the value of Cronbach's Alpha coefficients for the questionnaire. For usage of information technology it was noticed that the Cronbach's Alpha value was equal to 0.853 for 4 items. Then for acceptance in using information technologies the Cronbach's Alpha was equal to 0.856 for 12 items in the questionnaire. Regarding the effect of information technology usage on customer acceptance at GTBank, the Cronbach's Alpha value was equal to 0.757. The results of Cronbach's Alpha coefficients showed that all the sections of the questionnaire were acceptable, reliable and valid because they were greater than 0.5 (Hamdan, Badrullah \& Shahid, 2011).

\section{Validity}

It was necessary to evaluate the research instruments using content validation, in collaboration with an expert in connecting logical setting of questions. The validity of the instrument was measured by calculating the valid coefficient (CVC) that equals to total number of valid items divided by the total of items; CVC $=$ valid Items / Total Items, CVI of customers $=11 / 12=0.92$. Validity is the most critical condition and can be referred to as the extent or degree to which a test measures what it was intended to measure and performs as it is planned to perform. As argued by Amin (2005); the questionnaires were considered to be valid when the maximum content index was at least 0.7 .

\section{Data Analysis Procedure}

This is the process of categorizing, transforming and modelling data with the purpose of making recommendations, generalizations and conclusions. The filled-in questionnaires were edited for consistency. Descriptive analysis techniques were used in consistence with the research design. Statistical Package for Social Sciences (SPSS 16.0) was the tool chosen for quantitative data analysis. Quantitative data was coded to enable the responses to be grouped into categories prior to data entry. Descriptive statistics such as frequencies, percentages, weighed mean and standard deviation were used mainly to summarize the data. Likert, scales were analysed using weighted means and standard deviation. The relationship between the independent variables and dependent variables was determined using multiple regression analysis. Tables were used in presenting the analysed data. Data was categorized relevant thematic areas and analysis, thereof, based on the prevalence of the themes and subthemes in addition to their relevance to the topic. The regression model that was used to test the relationship between the variables were based on the following stochastic equation:

$\mathrm{Y}=\mathrm{a} 0+\mathrm{b} 1 \mathrm{X} 1+\mathrm{b} 2 \mathrm{X} 2+\ldots+\mathrm{bn} \mathrm{Xn}+\varepsilon$

$\mathrm{Y}=\mathrm{a}+\mathrm{b} 1 \mathrm{X} 1+\mathrm{b} 2 \mathrm{X} 2+\mathrm{b} 3 \mathrm{X} 3+\varepsilon$

$\mathrm{Y}=\mathrm{a}+\mathrm{b} 1$ (use of Internet Banking technology) $+\mathrm{b} 2$ (use of Mobile Banking technology) $+\mathrm{b} 3$ (use of ATM technology) $+\varepsilon$ 
Where Xn referred to the independent variable and Y the dependent variable; a and bn were the coefficient parameters and $\varepsilon$ is the error term. Qualitative data emanating from the interview guide was analyzed using content analysis (Kothari, 2012). Qualitative analysis included content analysis of information obtained using interview guides. The value obtained was used to generate research reports, suggestion and conclusions (Mukuru, 2015).

\section{Research Findings and Discussion}

\section{Introduction}

This was divided into four sections: demographic characteristics of sampled respondents, the usage of banking technologies, the customer acceptance in using technologies and effect of usage of information technologies on customer acceptance at Guaranty Trust Bank, Kigali, Rwanda.

\section{Demographic Characteristics of Respondents}

The general information on the respondents of the study included; age, education level, gender, language spoken and experience of technology usage by respondents. These demographic characteristics were considered to be significant because they helped to understand the characteristics of customers of GTBank. A total of 401 questionnaires were distributed to the sampled respondents, according to the proposed and approved plan. Nevertheless, 385 respondents completed and returned the questionnaires leading to a $96 \%$ rate of returns. This proportion was considered sufficient to proceed with the analysis and subsequent interpretation of data.

\section{Age Distribution of Respondents}

Knowledge of the age of customers that who used information technology was important. Table 4.1 shows the age distribution of respondents.

Table 4.1: Age distribution of respondents

Source: Primary data

\begin{tabular}{|l|l|l|}
\hline Age (years) & Frequency & Percent $(\%)$ \\
\hline $18-25$ & 65 & 16.88 \\
\hline $26-35$ & 186 & 48.31 \\
\hline $36-45$ & 94 & 24.42 \\
\hline 46 and above & 40 & 10.39 \\
\hline Total & 385 & 100.00 \\
\hline
\end{tabular}

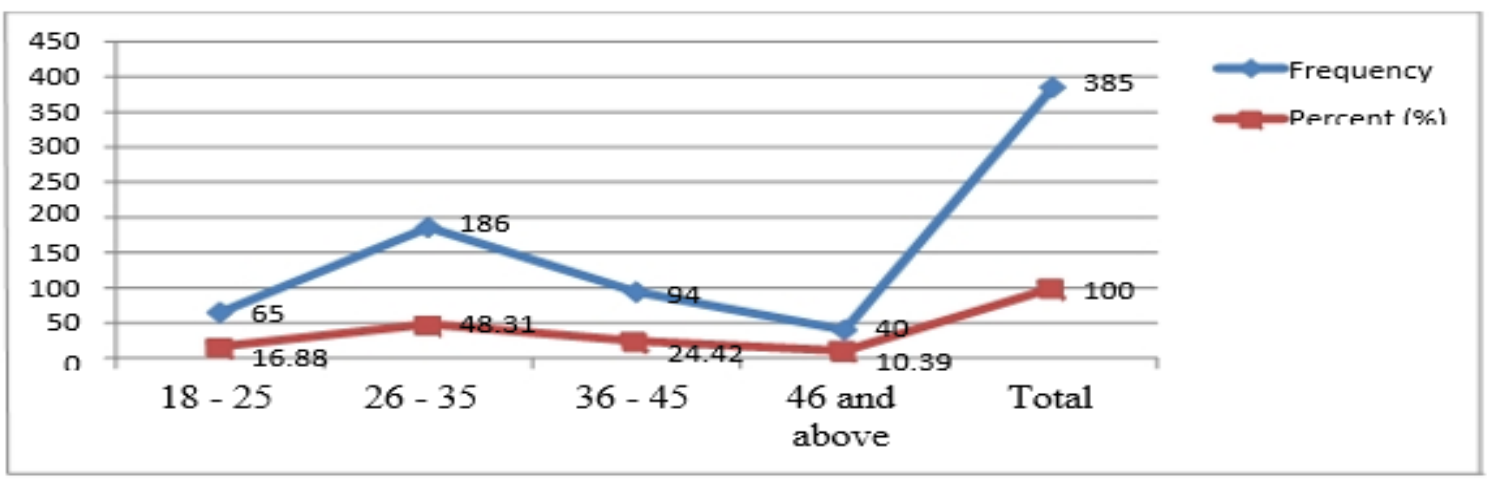

Figure 4.1: Age distribution of respondents 
Age

From Table 4.1 also indicated in Figure 4.1, it was found that majority of the respondents who used information technology were in the age group of 26-35 (48.31\%). The study also found that the least number of respondents were in age group of 46 and above (10.39\%). Furthermore, it can also be observed that majority of the respondents based on questionnaire were between 26 and 35 years $(48.31 \%)$. Therefore, this category of respondents was the most involved in information technology usage at GT Bank.

\section{Gender Distribution}

Table 4.2 indicates the distribution of respondents based on their gender.

Table 4.2 Gender distribution of respondents

Source: Primary data

\begin{tabular}{|l|c|c|}
\hline Gender & Frequency & Percent (\%) \\
\hline Male & 203 & 52.73 \\
\hline Female & 182 & 47.27 \\
\hline Total & 385 & 100.00 \\
\hline
\end{tabular}

From Table 4.2, males comprised a slightly greater proportion $(52.73 \%)$ of information technology users compared to females (47.27\%). These proportions were generally perceived to be roughly within the same range of similarity and comparability.

\section{Education Level}

Table 4.3 shows the distribution of GTBank customers according to their educational level.

Table 4.3: Highest education level of respondents

\begin{tabular}{|l|c|c|}
\hline Highest Educational Level & Frequency & Percent (\%) \\
\hline High School & 277 & 71.94 \\
\hline Undergraduate & 83 & 21.56 \\
\hline Graduate & 19 & 4.94 \\
\hline Other & 6 & 1.56 \\
\hline Total & 385 & 100.00 \\
\hline
\end{tabular}

Source: Primary data

From Table 4.3, the highest education level of respondents indicated that 277 out of 385 respondents $(71.94 \%)$ had high school level of education. University graduates were the minority $(26.50 \%)$.

\section{Language Proficiency Distribution of Respondents}

The respondent's proficiency in language used to interact with the information technology was essential. Table 4.4 shows the language proficiency distribution of respondents.

Table 4.4: Language proficiency of respondents

\begin{tabular}{|l|c|c|}
\hline Language & Frequency & Percent (\%) \\
\hline Kinyarwanda & 307 & 79.74 \\
\hline
\end{tabular}


Source: Primary data

\begin{tabular}{|l|c|c|}
\hline French & 24 & 6.23 \\
\hline English & 51 & 13.25 \\
\hline Others & 03 & 0.78 \\
\hline Total & 385 & 100.00 \\
\hline
\end{tabular}

From Table 4.4, it shows that $307(79.74 \%)$ respondents were found to be proficient in Kinyarwanda language. This was followed by English language.

\section{Experience of Information Technology Usage}

Sampled Customers of GT Bank were asked to indicate how long they had used information technology provided by the bank for various transactions. Table 4.5 provides a summary of information obtained:

Table 4.5: Experience of customer in usage of information technology

\begin{tabular}{|l|c|c|c|}
\hline Years of experience & $\mathbf{N}$ & Observed frequency & Percentage \\
\hline Less than 1 & 385 & 74 & $(19.22 \%)$ \\
\hline $1-2$ & 385 & 299 & $(77.66 \%)$ \\
\hline Above 2 & 385 & 12 & $(3.12 \%)$ \\
\hline
\end{tabular}

Source: Primary data

From Table 4.5, findings showed that the majority 299 (77.66\%) had one to two years' experience in using information technology provided by GT Bank. Information technology usage was high, thus indicating high customer acceptance.

\section{Usage of Information Technology}

Table 4.6 shows a summary of how often respondents used the information technology provided by GT Bank.

Table 4.6: How often Respondents Used the Technologies at GT Bank

\begin{tabular}{|c|c|c|c|c|c|c|c|c|}
\hline Technologie & $\mathbf{N}$ & $\begin{array}{c}\text { Very } \\
\text { often } \\
5\end{array}$ & $\begin{array}{c}\text { Often } \\
4 \\
\end{array}$ & $\begin{array}{c}\text { Some } \\
\text { time } \\
3 \\
\end{array}$ & $\begin{array}{c}\text { Rarely } \\
2 \\
\end{array}$ & $\begin{array}{c}\text { Never } \\
1 \\
\end{array}$ & $\begin{array}{c}\text { Weighted } \\
\text { Mean }\end{array}$ & $\begin{array}{l}\text { Std. } \\
\text { Dev. }\end{array}$ \\
\hline \multirow{2}{*}{$\begin{array}{l}\text { Internet } \\
\text { Banking }\end{array}$} & 385 & 0 & 0 & 270 & 106 & 09 & & \\
\hline & & $(0 \%)$ & $(70.13 \%)$ & $(27.53 \%)$ & $(02.34 \%)$ & $(0 \%)$ & 2.68 & 0.516 \\
\hline \multirow{2}{*}{$\begin{array}{l}\text { Mobile } \\
\text { Banking } \\
\end{array}$} & 385 & 367 & 18 & 0 & 0 & 0 & & \\
\hline & & $(95.32 \%)$ & $(4.68 \%)$ & $(0 \%)$ & $(0 \%)$ & $(0 \%)$ & 4.95 & 0.211 \\
\hline \multirow{2}{*}{$\begin{array}{l}\text { Automated } \\
\text { Teller } \\
\text { Machine }\end{array}$} & 385 & 155 & 230 & 0 & 0 & 0 & & \\
\hline & & $(40.26 \%)$ & $(59.74 \%)$ & $(0 \%)$ & $(0 \%)$ & $(0 \%)$ & 4.40 & 0.491 \\
\hline
\end{tabular}

(SD $<0.5$ or close to zero -Respondents responses were crowded around the weighted mean), (SD $>0.5$ or high -Respondents responses were dispersed from the weighted mean). Source: Primary data 
In Table 4.6, it was found that the weighted mean for Internet banking usage was 2.68. This meant that majority of the respondent's selection fell between sometime and rarely. The standard deviation for this attribute was 0.516. This meant that there was a general consensus (i.e. unanimity) with very few divergent answers among the respondents.

It was also found that the weighted mean for Mobile banking usage was 4.95. This meant that majority of the respondents' selection fell between very often and often. The standard deviation was 0.211 , meaning that respondents were generally in agreement, without divergent views.

In addition, it was found that the weighted mean for automated teller machine usage was 4.40. This meant that majority of the respondents' selection also fell between very often and often. The standard deviation was 0.491 and this meant that respondents were generally in agreement without divergent views.

Table 4.7 Factors that promote the usage of information technology in GT Bank

\begin{tabular}{|l|c|c|c|}
\hline Factors & $\mathbf{N}$ & Respondents & Percentage (\%) \\
\hline Reduced Time of Transactions & 385 & 314 & 81.16 \\
\hline Cost effectiveness & 385 & 298 & 77.40 \\
\hline Ease of use & 385 & 322 & 83.64 \\
\hline Technology Know - how & 385 & 269 & 76.88 \\
\hline
\end{tabular}

Source: Primary data

Table 4.7 shows that factors that promote usage of information technology in GT Bank, included Reduced Time of Transactions, Cost effectiveness, Ease of use, and Technology Knowhow. Respondents confirmed this with above $76 \%$ votes across the board.

Table 4.8: Ranking of preference of information technology provided by GT Bank

\begin{tabular}{|l|c|c|c|c|c|c|}
\hline $\begin{array}{l}\text { Information } \\
\text { Technologies }\end{array}$ & $\mathbf{N}$ & $\begin{array}{c}\text { Best } \\
\mathbf{1}\end{array}$ & $\begin{array}{c}\text { Next } \\
\mathbf{2}\end{array}$ & $\begin{array}{c}\text { Last } \\
\mathbf{3}\end{array}$ & $\begin{array}{c}\text { Weighted } \\
\text { mean }\end{array}$ & Std. Dev. \\
\hline $\begin{array}{l}\text { Use ATM } \\
\text { debit card } \\
\text { service }\end{array}$ & 385 & $\begin{array}{c}321 \\
(83.38 \%)\end{array}$ & $\begin{array}{c}61 \\
(15.84 \%)\end{array}$ & $\begin{array}{c}3 \\
(0.78 \%)\end{array}$ & 1.17 & 0.400 \\
\hline $\begin{array}{l}\text { Use internet } \\
\text { banking } \\
\text { transfer \& } \\
\text { utility } \\
\text { services mobile }\end{array}$ & 385 & $\begin{array}{c}271 \\
(70.39 \%)\end{array}$ & $\begin{array}{c}109 \\
(28.31 \%)\end{array}$ & $\begin{array}{c}05 \\
(1.30 \%)\end{array}$ & 1.31 & 0.490 \\
\hline $\begin{array}{l}\text { Use } \\
\text { transfer \& } \\
\text { utility } \\
\text { services }\end{array}$ & 385 & $\begin{array}{c}335 \\
(87.01 \%)\end{array}$ & $\begin{array}{c}43 \\
(11.17 \%)\end{array}$ & $\begin{array}{c}07 \\
(1.82 \%)\end{array}$ & 1.15 & 0.404 \\
\hline
\end{tabular}

(SD $<0.5$ or close to zero -Respondents responses were crowded around the weighted mean), (SD $>0.5$ or high -Respondents responses were dispersed from the weighted mean). Source: Primary data 
In Table 4.8, it was found that the weighted mean for use ATM debit card service was 1.17. This meant that majority of the respondents selection fell between best and next. The standard deviation for this attribute was 0.400 . This meant that there were very few divergent answers among the respondents.

It was also found that the weighted mean for use internet banking transfer and utility was 1.31. This meant that majority of the respondents' selection fell between best and next. The standard deviation was 0.490. This meant that there were very few divergent answers among the respondents.

In addition, it was found that the weighted mean for use mobile transfer and utility services was 1.15. This meant that majority of the respondents' selection also fell between best and next. The standard deviation was 0.404 and this meant that there were very few divergent answers among the respondents.

\section{Customer Acceptance in Using Information Technology Provided by GTBank}

The Tables 4.9, 4.10 and 4.11 indicated customer acceptance of information technology provided by GTBank.

Table 4.9: Views of customers regarding ATM at GTBank

\begin{tabular}{|c|c|c|c|c|c|c|c|c|}
\hline $\begin{array}{l}\text { Technology } \\
\text { Acceptance } \\
\text { ATM }\end{array}$ & $\mathbf{N}$ & $\begin{array}{c}\text { Strongly } \\
\text { Agree } \\
5\end{array}$ & $\begin{array}{c}\text { Agree } \\
4\end{array}$ & $\begin{array}{c}\text { Neutral } \\
3\end{array}$ & $\begin{array}{c}\text { Disagree } \\
2\end{array}$ & $\begin{array}{c}\text { Strongly } \\
\text { Disagree } \\
1\end{array}$ & $\begin{array}{c}\text { Weighted } \\
\text { Mean }\end{array}$ & $\begin{array}{l}\text { Std. } \\
\text { Dev. }\end{array}$ \\
\hline $\begin{array}{l}\text { Accomplish } \\
\text { work easier }\end{array}$ & 385 & $\begin{array}{c}253 \\
(65.71 \%)\end{array}$ & $\begin{array}{c}97 \\
(25.19 \%)\end{array}$ & $\begin{array}{c}0 \\
(0 \%)\end{array}$ & $\begin{array}{c}26 \\
(6.75 \%)\end{array}$ & $\begin{array}{c}9 \\
(2.34 \%)\end{array}$ & 4.45 & 0.625 \\
\hline \multirow[t]{2}{*}{ Easy to use } & \multirow[t]{2}{*}{385} & \multirow{2}{*}{$\begin{array}{c}298 \\
(77.40 \%)\end{array}$} & \multirow{2}{*}{$\begin{array}{c}77 \\
(20.00 \%)\end{array}$} & 0 & 8 & 2 & & \\
\hline & & & & $(0 \%)$ & $(2.08 \%)$ & $(0.52 \%)$ & 4.72 & 0.967 \\
\hline \multirow{2}{*}{$\begin{array}{l}\text { Login/Sign } \\
\text { off not easy }\end{array}$} & 385 & 10 & 65 & 41 & 81 & 188 & 2.03 & 0.850 \\
\hline & & $(48.83 \%)$ & $(45.19 \%)$ & $(1.30 \%)$ & $(2.86 \%)$ & $(2.60 \%)$ & & \\
\hline \multirow{2}{*}{$\begin{array}{l}\text { Use it } \\
\text { without } \\
\text { written } \\
\text { instruction }\end{array}$} & 385 & 243 & 142 & 0 & 0 & 0 & 4.63 & 0.483 \\
\hline & & $(63.12 \%)$ & $(36.89 \%)$ & $(0 \%)$ & $(0 \%)$ & $(0 \%)$ & & \\
\hline \multirow{2}{*}{$\begin{array}{l}\text { Recommend } \\
\text { it to a friend }\end{array}$} & 385 & 309 & 61 & 0.63908 & 03 & 04 & 4.74 & 0.639 \\
\hline & & $(80.26 \%)$ & $(15.84 \%)$ & $(2.08 \%)$ & $(0.78 \%)$ & $(1.04 \%)$ & & \\
\hline
\end{tabular}

(SD $<0.5$ or close to zero -Respondents responses were crowded around the weighted mean), (SD $>0.5$ or high -Respondents responses were dispersed from the weighted mean). Source: Primary data

Table 4.9 indicates, weighted mean corresponding to accomplishing work easier was found to be 4.45, with standard deviation of 0.625 . This meant that in line with this attribute, the views of customers fell between strongly agree and agree. Evidently, there were respondents with divergent opinions on the same.

Weighted mean corresponding to easy to use was found to be 4.72 and with this attribute, the views of customers fell between strongly agree and agree. The standard deviation was 0.967, which 
meant that respondents were in agreement with few differing views. Also weighted mean for login/sign off not easy was 2.03 with standard deviation 0.850 . The opinions of respondents fell between Neutral and disagree with few differing views.

Weighted mean corresponding to use it without written Instruction was found to be 4.63 and with this attribute, the views of customers fell between strongly agree and agree. The standard deviation was 0.483 which meant that respondents were in agreement with few differing views.

Lastly weighted mean corresponding to recommend it to a friend was found to be 4.74 and this shows views of respondents fell between strongly agree and agree. The standard deviation was 0.639 which meant that respondents were in consensus with few differing opinions.

Table 4.10: Views of customers regarding Internet Banking at GTBank

\begin{tabular}{|c|c|c|c|c|c|c|c|c|}
\hline $\begin{array}{l}\text { Technology } \\
\text { Acceptance } \\
\text { Internet } \\
\text { banking }\end{array}$ & $\mathbf{N}$ & $\begin{array}{c}\text { Strongly } \\
\text { Agree } \\
\\
5\end{array}$ & Agree & Neutral & Disagree & $\begin{array}{c}\text { Strongly } \\
\text { Disagree } \\
1\end{array}$ & $\begin{array}{c}\text { Weighted } \\
\text { Mean }\end{array}$ & $\begin{array}{l}\text { Std. } \\
\text { Dev. }\end{array}$ \\
\hline $\begin{array}{l}\text { Accomplish } \\
\text { work easier }\end{array}$ & 385 & $\begin{array}{c}20 \\
(5.19 \%)\end{array}$ & $\begin{array}{c}11 \\
(2.86 \%)\end{array}$ & $\begin{array}{c}308 \\
(80.00 \%)\end{array}$ & $\begin{array}{c}35 \\
(9.09 \%)\end{array}$ & $\begin{array}{c}11 \\
(2.86 \%)\end{array}$ & 2.98 & 0.643 \\
\hline \multirow{2}{*}{$\begin{array}{l}\text { Login/Sign } \\
\text { off not easy }\end{array}$} & \multirow[t]{2}{*}{385} & \multirow{2}{*}{$\begin{array}{c}92 \\
(23.90 \%) \\
\end{array}$} & \multirow{2}{*}{$\begin{array}{c}191 \\
(49.61 \%) \\
\end{array}$} & 89 & 13 & 0 & 3.94 & 0.777 \\
\hline & & & & $(23.12 \%)$ & $(3.38 \%)$ & $(0 \%)$ & & \\
\hline \multirow{2}{*}{$\begin{array}{l}\text { Lack clear } \\
\text { guidelines }\end{array}$} & 385 & 0 & 0 & 299 & 75 & 11 & 2.75 & 0.496 \\
\hline & & $(48.83 \%)$ & $(45.19 \%)$ & $(1.30 \%)$ & $(2.86 \%)$ & $(2.60 \%)$ & & \\
\hline \multirow{2}{*}{$\begin{array}{l}\text { Use it } \\
\text { without } \\
\text { written } \\
\text { instruction }\end{array}$} & 385 & 0 & 0 & 207 & 172 & 06 & 2.52 & 0.530 \\
\hline & & $(0 \%)$ & $(0 \%)$ & $(53.77 \%)$ & $(44.68 \%)$ & $(1.56 \%)$ & & \\
\hline \multirow{2}{*}{$\begin{array}{l}\text { Recommend } \\
\text { it to a friend }\end{array}$} & 385 & 0 & 0 & & 358 & 27 & 1.93 & 0.256 \\
\hline & & $(0 \%)$ & $(0 \%)$ & $(0 \%)$ & $(92.99 \%)$ & $(7.01 \%)$ & & \\
\hline
\end{tabular}

(SD $<0.5$ or close to zero -Respondents responses were crowded around the weighted mean), (SD $>0.5$ or high -Respondents responses were dispersed from the weighted mean). Source: Primary data

Table 4.10 indicates, weighted mean corresponding to accomplishing work easier was found to be 2.92, with standard deviation of 0.643. This meant that in line with this attribute, the views of customers fell between Neutral and disagree. Obviously, there were respondents with divergent views on the same.

Weighted mean for login/sign off not easy was 3.94 with standard deviation 0.777 . The opinions of respondents fell between agree and neutral with differing views.

Weighted mean corresponding to Lack clear guidelines was found to be 2.75 and the standard deviation was 0.964 with this attribute, the views of customers fell between neutral and disagree. Weighted mean corresponding to use it without written Instruction was found to be 2.52 and with this attribute, the views of customers fell between neutral and disagree. The standard deviation was 0.530 . 
Lastly weighted mean corresponding to recommend it to a friend was found to be 1.93 and this shows views of respondents fell between disagree and strongly disagree. The standard deviation was 0.256. With all above attributes regarding Internet Banking, found that Internet banking was the least used information technology.

Table 4.11: Views of customers regarding Mobile Banking at GTBank

\begin{tabular}{|c|c|c|c|c|c|c|c|c|}
\hline $\begin{array}{l}\text { Technology } \\
\text { Acceptance } \\
\text { Mobile } \\
\text { banking }\end{array}$ & $\mathbf{N}$ & $\begin{array}{l}\text { Strongly } \\
\text { Agree } \\
5 \\
\end{array}$ & Agree & Neutral & Disagree & $\begin{array}{l}\text { Strongly } \\
\text { Disagree } \\
1\end{array}$ & $\begin{array}{l}\text { Weighted } \\
\text { Mean }\end{array}$ & $\begin{array}{l}\text { Std. } \\
\text { Dev. }\end{array}$ \\
\hline $\begin{array}{l}\text { Accomplish } \\
\text { work easier }\end{array}$ & 385 & $\begin{array}{l}322 \\
(83.64 \%)\end{array}$ & $\begin{array}{l}54 \\
(14.03 \%)\end{array}$ & $\begin{array}{l}04 \\
(1.04 \%)\end{array}$ & $\begin{array}{l}0 \\
(0 \%)\end{array}$ & $\begin{array}{l}05 \\
(1.30 \%)\end{array}$ & 4.79 & 0.587 \\
\hline \multirow{2}{*}{$\begin{array}{l}\text { Absence } \\
\text { immediate } \\
\text { connection to } \\
\text { the service }\end{array}$} & \multirow[t]{2}{*}{385} & \multirow{2}{*}{\begin{tabular}{|l|}
379 \\
$(98.44 \%)$
\end{tabular}} & \multirow{2}{*}{$\begin{array}{l}06 \\
(1.56 \%)\end{array}$} & 0 & 0 & 0 & 4.98 & 0.124 \\
\hline & & & & $(0 \%)$ & $(0 \%)$ & $(0 \%)$ & & \\
\hline \multirow{2}{*}{$\begin{array}{l}\text { Login/Sign } \\
\text { off not easy }\end{array}$} & 385 & 0 & 0 & 0 & 317 & 68 & 1.82 & 0.384 \\
\hline & & $(0 \%)$ & $(0 \%)$ & $(0 \%)$ & $(82.34 \%)$ & $(17.67 \%)$ & & \\
\hline \multirow{2}{*}{$\begin{array}{l}\text { Use it } \\
\text { without } \\
\text { written } \\
\text { instruction }\end{array}$} & 385 & 378 & 07 & 0 & 0 & 0 & 4.98 & 0.134 \\
\hline & & (98.18\%) & $(1.82 \%)$ & $(0 \%)$ & $(0 \%)$ & $(0 \%)$ & & \\
\hline \multirow{2}{*}{$\begin{array}{l}\text { Recommend } \\
\text { it to a friend }\end{array}$} & 385 & 380 & 05 & 0 & 0 & 0 & 4.99 & 0.113 \\
\hline & & $(98.70 \%)$ & $(1.30 \%)$ & $(0 \%)$ & $(0 \%)$ & $(0 \%)$ & & \\
\hline
\end{tabular}

(SD $<0.5$ or close to zero -Respondents responses were crowded around the weighted mean), (SD $>0.5$ or high -Respondents responses were dispersed from the weighted mean). Source: Primary data

Table 4.11 indicates, weighted mean corresponding to accomplishing work easier was found to be 4.79 , with standard deviation of 0.587 . This meant that in line with this attribute, the views of customers fell between strongly agree and agree. It is true, there were respondents with a few divergent views on the same.

Weighted mean corresponding to absence immediate connection to the service was found to be 4.98 and with this attribute, the views of customers fell between strongly agree and agree. The standard deviation was 0.125 , which meant that respondents were in agreement with few differing views.

Also weighted mean for login/sign off not easy was 1.82 with standard deviation 0.384 . The opinions of respondents fell between disagree and strongly disagree without differing views.

Weighted mean corresponding to use it without written Instruction was found to be 4.98 and with this attribute, the views of customers fell between strongly agree and agree. The standard deviation was 0.134 . 
Last but not least, weighted mean corresponding to recommend it to a friend was found to be 4.99 and this shows views of respondents fell between strongly agree and agree. The standard deviation was 0.113 which meant that respondents were in consensus without differing opinions.

\section{How Customer Acceptance was Affected by Information technology at GTBank}

Multiple linear regression was used to model the relationship between several explanatory variables and a response variable by fitting a linear equation to observed data.

$\mathrm{Y}=\mathrm{b} 0+\mathrm{b} 1 \mathrm{X} 1+\mathrm{b} 2 \mathrm{X} 2+\ldots \ldots \ldots \ldots \ldots \ldots \ldots+\mathrm{bk} \mathrm{Xk}+\varepsilon$

Independent variable: Xk, and Coefficient: bk, Unknown factor: $\varepsilon$, and Dependent variable: Y Y was: Customer acceptance

X1: Automated Teller Machine, X2: Mobile banking, X3: Internet banking.

Table 4.12: Multiple Regression Analysis Output

\begin{tabular}{|l|c|c|c|c|c|}
\hline Model & B & Std. Error & Beta & T & Sig. \\
\hline 1 (Constant) & -5.320 & 0.643 & -8.269 & 0.000 & -5.320 \\
\hline Automated teller machine & 0.926 & 0.058 & 0.360 & 16.053 & 0.000 \\
\hline Mobile banking & 0.144 & 0.133 & 0.024 & 1.080 & 0.281 \\
\hline Internet banking & 1.657 & .063 & .678 & 26.453 & 0.000 \\
\hline
\end{tabular}

Source: Primary data

$\mathrm{Y}=\mathrm{b} 0+\mathrm{b} 1 \mathrm{X} 1+\mathrm{b} 2 \mathrm{X} 2+\mathrm{b} 3 \mathrm{X} 3+\varepsilon$

$\mathrm{Y}=-5.320+0.926$ Automated teller machine +0.144 Mobile banking +1.657 Internet banking + 0.47346

Table 4.13: Regression model summary

\begin{tabular}{|l|c|c|c|c|}
\hline Model & R & R Square & Adjusted R Square & Std. Error of the Estimate \\
\hline 1 & $0.927^{\mathrm{a}}$ & 0.860 & 0.859 & 0.47346 \\
\hline
\end{tabular}

a. Predictors: (Constant), Internet banking, Mobile banking, automated teller machine Source: Primary data

The correlation coefficient $\mathrm{R}$ measures the strength between two variables. When $\mathrm{R}$ is close to 1 the linear correlation is described as strong positive. When $\mathrm{R}$ is close -1 the linear correlation is described as strong negative. The R-squared value, denoted by $\mathrm{R} 2$, is the square of the correlation. It measures the proportion of variation in the dependent variable that can be attributed to the independent variable. The study found the correlation coefficient $\mathrm{R}=0.927$ and $\mathrm{P}$-value $=0.001$. This meant that there was a very strong, positive, multiple correlation between independent variables including: Internet banking, Mobile banking, automated teller machine and dependent variable (customer acceptance). The $\mathrm{P}$ value $<0.05$ signified that the correlation was found to be significant at the $95 \%$ confidence level. It also found that the coefficient of determination R $2=0$. 859. This meant that $85.90 \%$ of total variation in Y could be explained by the stochastic model developed relating $\mathrm{x}$ (independent variables) to $\mathrm{Y}$ (dependent variable). The remaining 14.10\%, of the variability in $\mathrm{Y}$ was due to unexplained factors that were beyond the control of the research. 


\section{Findings from Interview Guide}

The respondents of the interview were GT Bank staff in charge of e-banking and branch managers respectively. Questions asked, were answered freely and content analysis of the same was done as follows:

(a) Interview for e-banking staff

1) What are the main measures put in place to address the following problems in the using ATM machine?

\section{Cards Get Blocked Often}

All three staff pointed out that customers forgot their password identification number and tried many times leading to the blocking of cards. Measures put in place required customers to fill the form requesting password reset and unlocking card. All blocked ATM cards were collected from the machine and taken to the customer care officer's desk. Thereafter, customers got back their ATM cards from the customer care officer of that branch, after appropriately identifying themselves.

\section{Machines Running Out of Cash Often During Weekends}

Two out of three staff cited that some branches did not open during weekends and this increased the number of customers who used ATM cards for withdrawals. This led the machines to run out of cash. Monitoring team was put in place. One of the three staff had no answer.

\section{Reduction of Balance Without Cash Payment}

Respondents admitted that this happened, however customers were refunded their money after confirming the claim and cross-checking it.

Table 4.14: Measures put in place to address problems in the using ATM machine

\begin{tabular}{|c|l|}
\hline \multicolumn{1}{|c|}{ ATM problems } & \multicolumn{1}{c|}{ e-banking staff response } \\
\hline a) Cards get blocked often & $\begin{array}{l}\text { Customers got back their ATM cards from the customer } \\
\text { care officer of the branch, after appropriately identifying } \\
\text { themselves. }\end{array}$ \\
\hline b) $\begin{array}{l}\text { Machines running out of } \\
\text { cash often during weekends }\end{array}$ & Monitoring team was put in place. \\
\hline c) $\begin{array}{l}\text { Reduction of balance } \\
\text { without cash payment }\end{array}$ & Customers were refunded their money after confirming \\
\hline
\end{tabular}

Source: Primary data

2) Which of the following technology is most used by customers?

\section{ATM}

ATM was the second most used technology, based on transaction volume.

\section{Internet Banking}

Internet banking was the third most used technology based on transaction volume. 


\section{Mobile Banking}

Mobile banking was the first most used technology based on transaction volume.

3) What are the problems reported by customer in using technologies?

\section{ATM}

Locked cards and resetting of passwords.

Internet Banking

Customers doubted security of their transactions due to prevalence of cybercrimes.

\section{Mobile Banking}

Password reset.

4) Does the company provide regular clarifications to customers, helping them to prevent being victimized by robbery or identity theft?

\section{If yes how?}

All respondents replied in the affirmative and added that, transaction alerts are sent to customers.

\section{Interview for Branch Managers}

1) Do you have any information technology policy in place?

All the five branch managers replied in agreement that there was an information technology policy in their respective organizations.

2) How was the information technology policy used?

The policy dealt with the provision of information technology resources by GTBank and the associated responsibility of authorized users when accessing these information technology resources. These resources included, but were not limited to, the Bank network, computer systems and software, access to the Internet, electronic mail, telephony and related services. This was confirmed by four branch managers and one branch manager had no comment.

3) How often do you update information technology policy?

All respondents admitted that information technology at GTBank was updated on quarterly basis.

4) How is customer training conducted on Information technology usage?

All respondents said that training was provided orally whenever customers visited branches of GTBank.

5) What are your suggestions and recommendations for improving information technology usage?

The respondents suggested that network downtime incidences should be resolved; Information technology used by GTBank was based on a fully functional network and when connectivity was broken, it inconvenienced both staff as well as customers. Another suggestion was customer training on information technology usage guidelines and security. In summation, the implication 
was that the rationale was sufficient as the interview stands. It had enough value to be included in a collection of study and influence of the different practices in GTBank.

\section{Summary, Conclusion and Recommendations}

Objective one was to assess the usage of Information technology by customers at GTBank Kigali, Rwanda. Findings in Table 4.6 showed that Mobile banking and ATM with 4.95 and 4.40 weighted mean respectively. This indicated that were more used than internet banking. Table 4.7 Mobile banking and internet banking were secured than ATM, Table 4.8 revealed the factors that promotes usage of information banking technologies; reduced time of transactions, cost effectiveness, ease of use, technology Knowhow, 100\% confirmed by GTBank customers. Tables 4.9, 4.10 and 4.11 indicated that ATM and Mobile banking were more used than internet banking due to their features.

The second objective was to assess Customer Acceptance in using the information technology. Tables 4.9 revealed that ATM features were more accepted compared to Internet banking and Mobile banking features. Table 410 showed that Internet banking due to its difficult technological knowhow requirement, customer can not recommend it to friends. Table 4.11 showed that Mobile banking was the most used information technology, as indicate by weighted mean and customer confirmed that it had convenient features for use.

The last objective was concerned with determination of the effect of Information technology on Customer Acceptance at GTBank Kigali, Rwanda. Multiple regression analysis was carried out to determine the relationship between the Information technology usage (independent variable) and Customer acceptance (dependent variable) at GTBank Kigali, Rwanda.

Table 4.13 showed that multiple correlation coefficient $\mathrm{R}=0.927$ for Information banking technologies used by customers in GTBank Kigali, Rwanda indicates a good level of prediction.

Furthermore, it was found that coefficient of determination R $2=0.859$, meaning that $85.90 \%$ of total variation in customer acceptance could be explained by the relationship between information banking technologies and customer acceptance at in GTBank Kigali Rwanda and the remaining total variation of $14.10 \%$ are unpredictable due to factors beyond the research control.

\section{Conclusion}

The study concluded that Mobile banking and ATM were the most used than Internet banking due to its inconvenient features to customers. Internet banking and Mobile banking, however were found to have been secure than ATM. Mobile banking was more preferable than internet banking and ATM.

The study confirmed that Mobile banking, ATM were more accepted compared to internet banking. Internet banking required technological Know-how. Inconvenient features which required a certain level of education hence for layman was not easy. From $R=0.927$ and $R 2=$ 0.859 , there was a very strong, positive, correlation between information technology usage and 
customer acceptance as was carried out in GTBank Kigali, Rwanda. The P-value was found to be 0.001 signifying that the correlation was a statistically significant one.

\section{Recommendations}

Subsequently, these were the recommendations to GTBank Kigali, Rwanda:

- In the short term, it is recommended to GTBank Kigali, Rwanda that: more training of customers and awareness skills about internet banking technology should be provided to customers. Consistent maintenance of ATM machines, due to persistent break down and lack of cash on query.

- In the medium term, The management of GTBank should plan upgrading existing information technology to fit to new requirements like agency banking features.

- In the long term, the management should formulate a better information technology policy and laws regulating the usage of information technology. Provision of information technology security awareness, to increase trust of customer to use information technology.

\section{References}

[1] Aboelmaged, M.G., \& Gebba, T.R. (2013). Mobile Banking Adoption: An Examination of Technology Acceptance Model and Theory of Planned Behavior. International Journal of Business Research and Development, 2(1), 35-50.

[2] AbuShanab, E., Pearson, J. M., \& Setterstrom, A. J. (2010). Internet banking and customers' acceptance in Jordan: The unified model's perspective. Communications of the Association for Information Systems, 26(1), 494-496. Retrieved June, 2015 from http://aisel.aisnet.org/cgi/viewcontent.cgi?article

[3] Adepoju, A. S. (2010). Challenges of Automated Teller Machine (ATM) Usage and Fraud Occurrences in Nigeria - A Case Study of Selected Banks in Minna Metropolis. Journal of Internet Banking and Commerce,12(2), 1-2.

[4] Andrews, M. Jefferis, K. and Murgatroyd, P. (2012). Rwanda: Financial Sector Development Program II, p.1 Retrieved June, 2015 from http://www.minecofin.gov.rw/fileadmin/user_upload/Rwanda_FSDP_II_October_11_2012.pdf

[5] Anitha. K, Saranya. J, Dr. Vasantha, S. (2013). An Exploratory Study on Usage of Technology in Banking Sector. 2(11), 6487. Retrieved May, 2015 from http://www.ijirset.com/upload/2013/november/74_An\%20Exploratory.pdf

[6] Berger, E., \& Nakata, C. (2013). Implementing technologies for financial service innovations in base of the pyramid markets. Journal of Product Innovation Management, 30(6), 1199-1211.

[7] Bhulai, S., Sivasubramanian, S., Van Der Mei, R., \& Van Steen, M. (2007). Modeling and predicting end-to-end response times in multi-tier Internet applications. In Managing Traffic Performance in Converged Networks (pp. 519-532). Springer Berlin Heidelberg.

[8] Engwanda, M.N. (2015). Mobile Banking Adoption in the United States: A Structural Equation Modeling Analysis. International Journal of E-Services and Mobile Applications, 7 (3), 18-30. Retrieved on November 09, 2015 from http://econpapers.repec.org/article/iggjesma0/v_3a7_3ay_3a2015_3ai_3a3_3ap_3 a18-30.htm

[9] Fraenkel, J. R., Wallen, N. E., \& Hyun, H. H. (1993). How to design and evaluate research in education (Vol. 7). New York: McGraw-Hill.

[10] Guaranty Trust Bank (2015). GTBank Rwanda Banking made easy. Retrieved June, 2015 from http://GTBank.co.rw 
[11] Guaranty Trust Bank (2016). E-Banking GTBank Rwanda. Retrieved June, 2016 http://gtbank.co.rw/home/product/e-banking

[12] Israel G.D., (2013), Determining sample size (3rd Ed.). Gainesville: University of Florida.

[13] Kamel, S. \& Hassan, A.(2003). Assessing the Introduction of Electronic Banking in Egypt Using the Technology Acceptance Model, Retrieved march 2, 2015, from http://www.irma-international.org/viewtitle/44530/

[14] Kamel, S. (2005). The use of information technology to transform the banking sector in developing nations. Retrieved January 5, 2016, from http://www.tandfonline.com/doi/pdf/10.1002/itdj.20023

[15] Kothari C. R. (2012). Research Methodology, 2nd Ed. New Delhi: New Age International Publishers.

[16] Lassar, W. M., Manolis, C., \& Lassar, S. S. (2005). The relationship between consumer innovativeness, personal characteristics, and online banking adoption. International Journal of Bank Marketing, 23(2), 176-199. Retrieved September, 2015 from http://dx.doi.org/10.1108/02652320510584403

[17] Lichtenstein, S., \& Williamson, K. (2006). Understanding consumer adoption of internet banking: an interpretive study in the Australian banking context. Journal of Electronic Commerce Research, $7(2), 50$.

[18] Mubaraka, C.M., Uba, Z., \& Gokyalya, S. (2013). Adoption and Use of E-Technologies in Selected Commercial Banks in Uganda. Global Journal of Commerce and Management Perspective, 2(3), 132-135.

[19] Mukhtar, M. (2015). Perceptions of UK Based Customers toward Internet Banking in the United Kingdom. Journal of Internet Banking and Commerce, 20(1), 10-38.

[20] Mukuru, S.A. (2015). Management Information System and Execution of Academic Processes: A Case Study of Mount Kenya University, Kigali Campus, Rwanda. Unpublished thesis dissertation, Mount Kenya University, Kigali, Rwanda.

[21] Mwaikali, E.J.(2014). Assessment of Challenges Facing Customers in Automated Teller Machines in the Banking Industry in Tanzania: A Case of Some Selected Banks in Tanzania. International Journal of Research in Business and Technology, 4(3), 78- 80.

[22] Ngango, A., Mbabazize, M., \& Shukla, J. (2015). E-Banking and Performance of Commercial Banks in Rwanda a Case of Bank of Kigali. European Journal of Accounting Auditing and Finance Research, 3(4), 25 -27.

[23] Ongus, R. W., \& Lukania, B. J. (2013). Effects of Information Technology Application on Service Delivery by Cosmopolitan Savings and Credit Cooperative Organization, Nakuru County, Kenya. African Journal of Education, Science and Technology, 144. Retrieved August, 2015 from http://www.africanjest.com/wp-content/uploads/2014/11/AJEST-Vol-1-No-3.pdf\#page=154

[24] Pikkarainen, T., Pikkarainen, K., Karjaluoto, H., \& Pahnila, S. (2004). Consumer acceptance of online banking: an extension of the technology acceptance model. Internet research, 14(3), 224235.

[25] Venkatesh, V., Morris, M. G., Davis, G. B., \& Davis, F. D. (2003). User acceptance of information technology: Toward a unified view. MIS quarterly, 425-478.

[26] Vijayan, p.(2005). Multimedia Banking and Technology Acceptance Theories. JIBC, 1 (1), 1-2.

[27] Wang, Y. S., Wang, Y. M., Lin, H. H., \& Tang, T. I. (2003). Determinants of user acceptance of Internet banking: an empirical study. International Journal of service industry management, 14(5), 501-519. retrieved September, 2015 from http://dx.doi.org/10.1108/09564230310500192

[28] Yüksel, M. A. (2011). Customer's Perspectives and Risk Issues on E-Banking in Turkey; Should We Still be Online? Journal of Internet Banking and Commerce,16(1), 11-13.

\footnotetext{
*Corresponding author.

E-mail address: Johnkwizera2011@gmail.com/raymondongus@ gmail.com
} 